\title{
The impact of tax incentives on the process of innovation creation in Polish economy
}

\author{
[ Anna Wildowicz-Giegiel, R. Dziemianowicz ]
}

\begin{abstract}
The effective implementation of fiscal instruments in innovation policy, can help countries to achieve sustained economic growth and improve their competitiveness. In case of Poland, the lack of fiscal incentives which could increase business sector's propensity to invest in $R \& D$ and encourage greater cooperation in the area of research and innovation, appears to be the serious hindrance in narrowing the technology gap in comparison to the most innovative economies. The paper analyzes the most popular types of $R \& D$ tax incentives, taking into account their effectiveness, such as tax credits, enhanced allowances, accelerated depreciation or preferential tax rates. The results of conducted analysis reveal that the existing fiscal incentives in Poland encourage only imitation or are directed to the selected entities. The Polish model of $R \& D$ financing is based mainly on state subsidies and structural funds, however following the solutions of more experienced countries, there is an urgent need to introduce new fiscal incentives in order to increase the amount of business expenditure on $R \& D$.
\end{abstract}

Keywords - tax incentives, $R \& D$, innovation.

Anna Wildowicz-Giegiel/Faculty of Economics and Management, Treasury Department

line 1 : University of Bialystok

line 2: Poland

Ryta Dziemianowicz/ Faculty of Economics and Management, Treasury Department

line 1:University of Bialystok

line 2: Poland

\section{Introduction}

It is commonly known that achieving growth, competitiveness and social welfare requires the favorable institutional environment shaped by the state policy aimed at supporting business entities which are involved in R\&D and knowledge commercialization. One of the tools for stimulating innovation and technology development is fiscal policy. Taking into account that innovation lies at the heart of the Europe 2020 strategy for smart, sustainable and inclusive growth, $26 \mathrm{EU}$ member states currently have some type of fiscal encouragement for R\&D. However, in Poland which still achieved poor results in innovation activity and was ranked as $26^{\text {th }}$ among the EU countries (IUS, 2014), the current tax incentives seem to be poor and do not encourage to innovation.

The aim of the paper is to analyze the different types of R\&D tax incentives applied on income taxes. The international comparison of $\mathrm{R} \& \mathrm{D}$ tax incentives allows to indicate the best practices in this area and recommend the most effective solutions worth regarding under the current income tax regime in Poland. For the purpose of the analysis the research hypothesis is assumed that tax incentives are the effective instruments supporting innovation and their implementation can have a positive impact on the weakest pillars of innovativeness in Poland, contributing to the increase in business R\&D spending and greater cooperation for innovation.

\section{Tax incentives vs. subsidies for innovation}

Tax incentives and direct funding through grants, contracts and loans are two policy instruments which are commonly used to stimulate business $R \& D$. The reasons for using such kind of instruments are market failures. Among the most important of them are: spillovers, asymmetric information, uncertainty and incomplete capital markets, indivisibility of large projects or coordination problems. The danger of imitation by rivals, asymmetric information between investors and inventors or sunk costs which generate serious barriers to starting R\&D activities, cause that government support for innovation is fully justified. The financial constrains concern particularly SMEs and start-ups that lack sufficient internal funding to finance their projects. In the face of financial constraints (whether internal or external), a risky and even uncertain investment in R\&D should be supported by government which can use direct and indirect methods. Their implementation depends mainly on firm size. It is observed that SMEs, especially young knowledge-intensive firms, prefer direct public funding and are less likely to use R\&D tax incentives. Taking into consideration the above mentioned difficulties associated with this category of investment, it is obvious that apart from public expenditure on $R \& D$, tax policy and direct funding can play an important role in stimulating R\&D. It should be simultaneously emphasized that direct public funding of $R \& D$ has a long tradition, even though according to the conservative economists and policy makers tax incentives are more market neutral, in contrast to the instrument which usually targets particular technologies or 
phases of the R\&D cycle. The establishment of the set of instruments which could encourage business sector to invest more in R\&D requires to consider the most important pros and cons for tax incentives and direct funding that are presented in the Table I (Mohnen, 2013; Burnat-Mikosz and Turczyk, 2013).

\section{TABLE I. DIRECT FUNDING vs. TAX INCENTIVES}

\begin{tabular}{|c|c|}
\hline JG & JCENTIVES \\
\hline \multicolumn{2}{|c|}{ Advantages } \\
\hline $\begin{array}{l}\text { Direct support through subsidies is } \\
\text { targeted precisely towards projects } \\
\text { that offer high marginal social rates } \\
\text { of return to investment in } \\
\text { knowledge and are socially } \\
\text { desirable, e. g. health care, defense. }\end{array}$ & $\begin{array}{l}\text { Tax credits and allowances are } \\
\text { neutral, simple and market- } \\
\text { orientated tool which does not } \\
\text { distort market mechanism. It is } \\
\text { presumed that private sector knows } \\
\text { the market needs better than pure } \\
\text { researchers and state officials. }\end{array}$ \\
\hline $\begin{array}{l}\text { Direct funding is more appropriate } \\
\text { for SMEs and technological start- } \\
\text { ups because of the potential losses } \\
\text { which may occur in the early years. }\end{array}$ & $\begin{array}{l}\text { Tax incentives are more } \\
\text { predictable, and accessible for } \\
\text { business. They are targeted to all } \\
\text { R\&D performers, not to the } \\
\text { selected entities, irrespective of } \\
\text { project features and quality as long } \\
\text { as expenses can be qualified as } \\
\text { R\&D according to the tax code. }\end{array}$ \\
\hline $\begin{array}{l}\text { From the point of view of } \\
\text { government, direct funding allows } \\
\text { for better control of use of funds } \\
\text { and guarantees more effective } \\
\text { planning and monitoring in the } \\
\text { context of budgetary implications }\end{array}$ & $\begin{array}{l}\text { Tax incentives may generate lower } \\
\text { administration costs at the firm } \\
\text { level. It depends on the adoption of } \\
\text { certain tax policy which allows for } \\
\text { better budget control. }\end{array}$ \\
\hline $\begin{array}{l}\text { Direct funding gives the possibility } \\
\text { to use grants for the purpose of } \\
\text { building the cooperation network } \\
\text { between universities and } \\
\text { enterprises. }\end{array}$ & $\begin{array}{l}\text { The fiscal incentives in the form of } \\
\text { additional deduction from taxable } \\
\text { income or deduction from the tax } \\
\text { payable encourage private sector to } \\
\text { increase their investment in R\&D. }\end{array}$ \\
\hline $\begin{array}{l}\text { Direct public funding is obtained } \\
\text { on the basis of the submitted } \\
\text { application to the public agency } \\
\text { which arbitrarily choose the best } \\
\text { proposals taking into account their } \\
\text { content, technical feasibility and } \\
\text { market potential. }\end{array}$ & $\begin{array}{l}\text { R\&D tax incentives do not favor } \\
\text { the selected areas and entities } \\
\text { which are perceived as the } \\
\text { monopolistic privileges contrary to } \\
\text { the principle of free competition. }\end{array}$ \\
\hline \multicolumn{2}{|c|}{ Disadvantages } \\
\hline $\begin{array}{l}\text { There is a high risk associated with } \\
\text { providing support only for the } \\
\text { selected enclaves or entities and it } \\
\text { can be a source of distortion in } \\
\text { market competition. }\end{array}$ & $\begin{array}{l}\text { Tax incentives are likely to favor } \\
\text { projects that generate greater profits } \\
\text { in the short-run. Fiscal incentives } \\
\text { are simply ineffective in raising } \\
\text { private R\&D investment. It is } \\
\text { argued that the response elasticity } \\
\text { is so low it would take a huge tax } \\
\text { change to generate the socially } \\
\text { desirable level of spending. }\end{array}$ \\
\hline $\begin{array}{l}\text { Submitting a grant application and } \\
\text { having it evaluated by experts is } \\
\text { more costly, time-consuming, and } \\
\text { administrative costs during the } \\
\text { realization of project are high. }\end{array}$ & $\begin{array}{l}\text { R\&D tax incentives benefit more } \\
\text { large firms that SMEs which are } \\
\text { usually dynamic and creative but } \\
\text { suffer from the financial constrains. } \\
\text { Using the tax incentives is possible } \\
\text { if the enterprise generates income } \\
\text { or tax liabilities }\end{array}$ \\
\hline $\begin{array}{l}\text { Direct public funding can be a } \\
\text { substitute for private R\&D } \\
\text { expenditure if, as the result of the } \\
\text { decision of public agency the } \\
\text { groups represented by the powerful } \\
\text { lobbyists are supported. }\end{array}$ & $\begin{array}{l}\text { All kind of fiscal incentives } \\
\text { addressed to the broader groups of } \\
\text { recipients are extremely expensive } \\
\text { and mean lower government budget } \\
\text { income }\end{array}$ \\
\hline
\end{tabular}

\section{The types of R\&D tax incentives and their implementation}

The popularity of tax incentives is getting into importance and the vast majority of countries, including the EU Member States, provide a favorable tax treatment of R\&D expenditures. The most commonly used R\&D tax incentives differ significantly across countries regarding their generosity, design and targeting group of entities. They can be provided at the front-end and back-end of the innovation cycle. The frontend tax incentives include incurred $R \& D$ expenditures such as:

- enhanced allowances, along with "super deduction", are aimed at effectively decreasing the base of taxable income,

- tax credits which are amounts deducted from the tax a corporation must pay to tax authorities,

- tax deferrals understood as tax reliefs in the form of delay in tax payment. Accelerated depreciation scheme belongs to one of this kind of instruments.

In turn, patent-box regimes are the examples of back-end incentives and can be identified with preferential tax rates. They cause the reduction of the corporate income for certain income arising from the exploitation of IP generally through a $50-80 \%$ deduction or exemption of qualified IP income (Global, 2014). It is worth underlining that tax credits, enhanced allowances and accelerated depreciation, are the most widely used tax incentives, while patent boxes seem to be a relatively new policy instrument. As it was mentioned above, the distinguished instruments differ due to: the scope of the policy, including the type of $R \& D$ incentive and costs covered, targeting of specific groups of business entities, according to their size, age, region, etc. and organization (their tax construction and generosity). Moreover, in the case of tax credits and tax allowances their deductions can be based on: the volume of R\&D expenditure (volume incentives), the increment of that volume (incremental incentives) or a mixedsystem of volume-based and incremental tax incentives.

The descriptive overview of tax incentives offered by the selected EU countries and other economies belonging to the group of leaders according to The Global Innovation Index are presented in Table II (A Study, 2014; Summary, 2014 and Global, 2014). It can be emphasized that fiscal incentives for business $R \& D$ vary considerably across countries. The majority of them introduced more than one type of fiscal encouragement for $R \& D$. These tax incentives are mainly applied on corporate income taxes and tax credits, enhanced allowance or accelerated depreciation belong to the most popular of them. It has to be noticed that The Netherlands and Japan rely mostly on tax incentives. France, Denmark, the United Kingdom or the United States implement both of the instruments, whereas exclusive reliance on direct funding is typical for Sweden, Finland and Germany (Busom, Corchuelo, Martinez-Ros, 2014). The general trend observed in the majority of countries which introduced $R \& D$ tax incentive 
schemes is growth of relief accessibility, amount of deductions as well as simplification of the relief construction.

TABLE II. THE OVERVIEW OF GLOBAL R\&D TAX INCENTIVES

\begin{tabular}{|c|c|}
\hline Country & $\begin{array}{l}\text { Types of incentives: Tax credit/ Enhanced allowances/ } \\
\text { Tax deferrals/Patent or Innovation Box }\end{array}$ \\
\hline $\begin{array}{l}\text { United } \\
\text { Kingdom }\end{array}$ & $\begin{array}{l}\text { Tax credit : } 10 \% \text { taxable credit (from April 2013) for large } \\
\text { companies and cash credits for loss position SMEs (up to } \\
24,75 \% \text { of the qualifying expenditure). } \\
\text { Enhanced allowances: } 130 \% \text { volume-based super deduction } \\
\text { for large companies and } 225 \% \text { volume-based super } \\
\text { deduction for SMEs. } \\
\text { Tax deferrals: The accelerated depreciation (at the rate of } \\
100 \% \text { ) is offered to all companies. No limit of maximal } \\
\text { costs that can be claimed is set. } \\
\text { Preferential tax rates: Patent Box provides } 10 \% \text { reduction } \\
\text { in the corporate income tax rate for profits made on patents } \\
\text { and specific medicinal or botanic innovation rights. }\end{array}$ \\
\hline Sweden & $\begin{array}{l}\text { Tax credit: From } 2014 \text { year } 10 \% \text { reduction of the paid } \\
\text { social security contributions, up to the EUR } 25000 \text { per } \\
\text { month) concerns only limited companies. A payroll } \\
\text { withholding tax credit is complementary to the R\&D } \\
\text { subsidy schemes. }\end{array}$ \\
\hline Finland & $\begin{array}{l}\text { Enhanced allowance: From } 2013 \text { year } 100 \% \text { deduction for } \\
\text { R\&D personnel wages, set against the corporate tax can be } \\
\text { used along with R\&D subsidies. The target groups are both } \\
\text { single proprietors and limited companies. The } \\
\text { supplementary relief can amount to EUR } 15000-400000 \\
\text { during the fiscal year } \\
\text { Tax deferrals: } 100 \% \text { deduction for capital investment } \\
\text { (machines and equipments) and } 20 \% \text { in case of building } \\
\text { related to R\&D activities. }\end{array}$ \\
\hline Netherlands & $\begin{array}{l}\text { Tax credit: wage tax credit of } 35 \% \text { (or } 50 \% \text { in case of start- } \\
\text { up companies) of the first EUR } 250000 \text { and } 14 \% \text { of the } \\
\text { remaining wage costs in } 2014 \text {. } \\
\text { Enhanced allowance: super deduction of } 160 \% \text { for } \\
\text { qualifying R\&D expenditures (other than wage costs) } \\
\text { Innovation box: } 8 \% \text { deduction of taxable income } \\
\text { generating from innovation or deduction of } 25 \% \text { of taxable } \\
\text { income with income capped at EUR } 100000 \text {. }\end{array}$ \\
\hline $\begin{array}{l}\text { United } \\
\text { States of } \\
\text { America }\end{array}$ & $\begin{array}{l}\text { Federal tax credit: } 20 \% \text { traditional credit or } 14 \% \text { alternative } \\
\text { simplified credit (ASC) provided for qualified research } \\
\text { expenses. } \\
\text { State tax credit: offer reduction of tax payable due to the } \\
\text { qualified R\&D expenditures from } 1,9 \% \text { to } 24 \% \text {. } \\
\text { Tax deferrals: federal tax facility for accelerated } \\
\text { depreciation of R\&D expenses (at the rate of } 100 \% \text { ). }\end{array}$ \\
\hline Denmark & $\begin{array}{l}\text { R\&D tax credit : } 25 \% \text { tax credit for companies in } 2014 \\
\text { year, set against the deficit that had occurred from R\&D } \\
\text { expenses. The maximum deduction cannnot exceed an } \\
\text { amount of } 3,36 \text { mln EUR). } \\
\text { Tax deferrals: The accelerated depreciation which allows } \\
\text { for an immediate write-off capital expenditures for R\&D. }\end{array}$ \\
\hline Germany & $\begin{array}{l}\text { There is no R\&D tax incentives. Instead of them } \\
\text { government offers non-repayable cash grants for eligible } \\
\text { R\&D projects, up to } 50 \% \text { of eligible expenses. Other } \\
\text { options are R\&D loans and guarantees. }\end{array}$ \\
\hline Japan & $\begin{array}{l}\text { Tax credit: equals } 8 \% \text { to } 10 \% \text { of qualifying expenses for } \\
\text { large companies or } 12 \% \text { in case of SMEs. The tax credit is } \\
\text { limited to } 20 \% \text { of the company's corporate income tax } \\
\text { liability. Additional incremental credits are offered for both } \\
\text { SMEs and large companies (limited to } 10 \% \text { of the } \\
\text { company's corporate income tax liability before the credit } \\
\text { is applied. } \\
\text { Another R\&D credit system is targeted at companies } \\
\text { conducting R\&D jointly with a qualified R\&D institutions } \\
\text { (universities). } \\
\text { R\&D income deduction: From the beginning of } 2012 \text { year } \\
\text { R\&D centers have been allowed to deduct } 20 \% \text { of their } \\
\text { income in the first } 5 \text { years. }\end{array}$ \\
\hline
\end{tabular}

\begin{tabular}{|c|c|}
\hline France & $\begin{array}{l}\text { Tax credit: } 30 \% \text { of the first EUR } 100 \text { million of qualified } \\
\text { R\&D expenses incurred during the tax year plus an } \\
\text { additional } 5 \% \text { of any amount in access of this threshold. } \\
20 \% \text { innovation tax credit is available for SMEs which } \\
\text { incurred expenditures for new prototypes or pilot assets. A } \\
\text { ceiling of eligible expenditure is set at EUR } 400000 \text {. } \\
\text { Tax deferrals: Equipment used in R\&D activities can be } \\
\text { subject to an accelerated amortization. The coefficients are } \\
1.5,2 \text { and } 2.5 \text {, depending on the standard duration of } \\
\text { amortization of fixed assets. } \\
\text { Preferential tax rates: Young innovative enterprise (JEI) are } \\
\text { free of corporate tax in the first year of participation and } \\
\text { receive a } 50 \% \text { reduction in the corporate tax in the second } \\
\text { year. The qualified firms are exempt from the social } \\
\text { security contributions for } 8 \text { years. } \\
\text { Patent box- revenues derived from licensing or sale of } \\
\text { patents or patentable technology are taxed at } 15 \% \text { reduced } \\
\text { rate. } \\
\text { The territorial economic contribution relief are offered for } \\
\text { current and future investment of companies that performed } \\
\text { certain types of activities within specific areas. } \\
\text { Apart from fiscal incentives, the direct funding in the form } \\
\text { of cash grants for collaborative R\&D projects is offered. }\end{array}$ \\
\hline
\end{tabular}

\section{Iv. The assessment of effectiveness of R\&D tax incentives}

In the literature several approaches to measure the impact of $R \& D$ tax incentives can be found. One of the methods of evaluating the effectiveness of $R \& D$ tax relief, is the comparison of the $\mathrm{R} \& \mathrm{D}$ expenditure before and after changes in tax incentives (Cordes, 1989) Many studies also rely on structural econometric models (Bloom, Griffith and Van Reenen, 2002) or propose quasi-natural experiments ( e.g. Hægland and Møen, (2007), Duguet, 2010) which are used to assess the ex post impact of R\&D tax incentives on firm R\&D investment (Bozio, Irac and Py, (2014), Szlęzak-Matusewicz, 2014). The overall generosity of tax incentives can be measured by the B-index (Warda, 2006). The B-index expresses the minimum cost effectiveness relationship with which investment in R\&D becomes paying under the conditions of a given tax regime. It is assumed that the more favorable a country's tax treatment of R\&D, the lower its Bindex. However, it is worth additionally stressing that in international comparisons, instead of using the B-index, the tax subsidy ratio being a difference between 1 and the B-Index is commonly used. If the index is higher than 0 , it indicates that the tax incentives influence business $R \& D$ investment positively, while the index lower than $\mathrm{O}$ means that the tax regime affects the amount of $R \& D$ expenditures negatively.

During the last two decades, the majority of countries have either implemented the incentives or expended the existing incentives. The assessment of generosity of R\&D tax incentives is presented in Table III (Stewart, Warda, Atkinson, 2012). It seems to be evident that the most advantageous for business sector systems of tax incentives are in force in France, Spain and Denmark. Moreover, it should be stressed that currently France, the Netherlands, the United Kingdom and Japan offer more generous treatment for SMEs than for large enterprises. All of the above countries are at the top of 
global rankings, regardless of the types of R\&D tax incentives used and the size of enterprises to which this support is targeted.

TABLE III. RATE OF TAX SUBSIDIES FOR \$1USD OF R\&D IN 2012

\begin{tabular}{|l|c|c|}
\hline \multirow{2}{*}{ Country } & \multicolumn{2}{|c|}{ Tax subsidy ratio } \\
\cline { 2 - 3 } & Large companies & SMEs \\
\hline France & 0,34 & 0,43 \\
\hline Denmark & 0,29 & 0,29 \\
\hline Netherlands & 0,14 & 0,33 \\
\hline Japan & 0,13 & 0,16 \\
\hline United Kingdom & 0,11 & 0,28 \\
\hline Spain & 0,35 & 0,35 \\
\hline Czech Republic & 0,2 & 0,2 \\
\hline United States & 0,06 & 0,06 \\
\hline Germany & $-0,02$ & $-0,02$ \\
\hline Sweden & $-0,01$ & $-0,01$ \\
\hline Finland & $-0,01$ & $-0,01$ \\
\hline Poland & $-0,01$ & $-0,01$ \\
\hline
\end{tabular}

It turns out that France is the leader among the EU Member States. In 2008 France established a new R\&D tax credit not only available for large companies but also SMEs. As a result, the subsidy for SMEs has effectively increased from 20 cent to 43 cents of every euro of R\&D invested, while in case of large companies from 15 to 34 cents per euro (IBEC, 2013). In turn, countries such as Germany, Finland or Sweden, regarded as one of the most innovative in the EU, do not have the effective R\&D tax incentive schemes implemented, but their business sector R\&D expenditures (BERD) are extremely high, above the EU average of 1,29\% GDP in 2013 (A Study, 2014; Business, 2015).

TABLE IV. BERD EXPENDITURE AND STATE AID FOR R\&D IN THE SELECTED EU COUNTRIES (AS \% GDP)

\begin{tabular}{|l|c|c|c|}
\hline Country & $\begin{array}{c}\text { BERD } \\
\text { expenditure }\end{array}$ & $\begin{array}{c}\text { Public } \\
\text { expenditure on } \\
\text { R\&D incentives }\end{array}$ & $\begin{array}{c}\text { Direct } \\
\text { government } \\
\text { funding of } \\
\text { BERD }\end{array}$ \\
\hline United Kingdom & 1,05 & 0,08 & 0,09 \\
\hline Sweden & 2,19 & n/a & 0,12 \\
\hline Finland & 2,29 & 0 (in 2011$)$ & 0,08 \\
\hline Netherlands & 1,14 & 0,15 & 0,04 \\
\hline Denmark & 1,99 & 0,05 & 0,05 \\
\hline Germany & 1,99 & 0 & 0,09 \\
\hline France & 1,44 & 0,26 & 0,12 \\
\hline
\end{tabular}

The considered economies, in promoting business sector $R \& D$ investment, rely mainly on direct government funding. Moreover, it is worthwhile to mention that, the key activator of $R \& D$ activity in case of them, is an extensive cooperation between enterprises and research institutes. To sum up, the data analysis presented in Table IV, allows to conclude that both fiscal incentives and direct funding have a positive impact on R\&D expenditures. However, it can not be forgotten that the necessary condition of greater intensity of R\&D activity should be the creation of favorable institutional environment, including fiscal incentives.

\section{v. The R\&D tax incentives in Poland. The new reform proposals}

The R\&D tax incentives regime is still under development in Polish economy. Unfortunately, the existing solutions differ considerably in comparison to the other countries. Currently, three types of incentives can be distinguished: tax deduction for new technology expenses, tax deduction for entities possessing the status of $R \& D$ center and tax exemption for special economic zones (SEZs). In accordance with The Personal Income Tax Act and the Corporate Income Tax Act in Poland (1991, Art 26c; 1992, Art 18b) the taxpayer can only deduct from its tax base up to $50 \%$ of expenditures incurred for the acquisition of new technology in the form of intangible assets. There is also the possibility to deduct from the tax base $100 \%$ of expenditure related to R\&D works regardless of their outcome and the accelerated depreciation of R\&D is offered. The entities with the status of small entrepreneur may also benefit from a tax credit, which is a relief consisting in deferral of payment regarding tax on income generating in the first year. The tax due with reference to such income should be paid by the taxpayer in installments within the next 5 consecutive years. Extra deductions are reserved for R\&D centers and SEZs. R\&D centers can make monthly contributions to an "innovative fund" amounting to $20 \%$ of revenue which are then treated as deductible costs. If the company is located in the SEZ, the entity benefits from corporate tax rate relief up to $50 \%$. R\&D centers are also eligible for a real estate tax exemption, as well as forest tax exemption.

In spite of introducing the $R \& D$ incentives system in Poland it should be simultaneously emphasized that the available fiscal instruments do not fulfill their function efficiently. The tax subsidy ratio for Poland is estimated at 0,01 (see Table IV). In 2013, according to the Ministry of Finance data only 31 enterprises taxed by the personal income tax and 75 - by the corporate income tax used the relief for purchase of new technology. This kind of technology tax relief is considered to be relatively low attraction to enterprises in Poland. The relief is directed only to entities acquiring a technology solution which had not been used worldwide for a period exceeding 5 years. What is more, the tax relief does not apply to taxpayers using the flat rate method and enterprises in SEZs. The list of qualified expenditures is also very limited because includes only costs of acquired technology in the form of intangibles, whereas the costs of internal $R \& D$ or costs refunded from other public aid sources do not qualify for the technology incentive. It means that costs of tangibles, materials and wages related to $R \& D$ activities can not be deducted.

The additional incentives reserved for $R \& D$ centers and SEZs seem not to be the effective way of encouraging towards innovation. Particularly, if the condition for achieving the status of R\&D center is to meet the following 
criteria: minimum net sales revenue at least EUR 1200 000, sales revenue of internal R\&D services or industrial property rights accounting for $20 \%$ of net revenue and no outstanding regulatory liabilities. As a result, in 2014 there were in Poland only 31 R\&D centers. Similarly, CIT exemption offered for entities conducting business activity in SEZs, up to 2026 year, is not sufficient incentive. In 2013, only 507 taxpayers carrying out business activity in the SEZs were beneficiaries of these incentive and the average amount of income tax exemption was 18002 PLN (Information, 2014).

It has to be underlined that current system of $R \& D$ incentives in Poland is dominated by direct funding. The available tax incentive such as new technology relief or tax deduction for R\&D centers implemented in 2006 play a marginal role. There is an urgent need to broaden the deduction base volume, including current expenditure on own R\&D activity and provide access to tax reliefs to entrepreneurs taxed by flat rates and lump-sum taxpayers. The existing instrument such as tax relief for new technology purchase should be replaced by regular tax allowance $(100 \%$ of qualified costs related to internal or external $R \& D$ activities) and credit tax because it is commonly thought that these instruments support the creation of innovation rather than imitation. It is proposed to redesign tax incentive scheme which will be a combination of both instruments available for young innovative start-ups and SMEs. Moreover, it should be noticed that the tax deduction offered for entities with the status of R\&D center is a typical output-related, which ought to be broaden by additional front-end incentives in the form of relief deducted from income or tax. In order to support cooperation between Polish enterprises and universities, special incentives such as reduction on tax rates or tax credit are recommended. It is also worth regarding the implementation of fiscal incentives available for early stage investors which provide funds to young innovative companies.

\section{vI. Conclusion}

Tax incentives are market-orientated instruments which can effectively stimulate R\&D. The conducted analysis confirms that over the last two decades, the majority of countries have invested in fiscal policy tools with the aim of fostering innovation. Polish law provides only one R\&D tax incentive a new technology tax relief available for large companies and SMEs. However, it is not the effective instrument. Firstly, this kind of incentive encourages mainly enterprises to imitation and does not stimulate innovation. Secondly, the incentive is not applied to all entities because the enterprises taxed by flat rate or lump-sum taxpayers, functioning in the SEZs and with the status of R\&D center are excluded. There are also special tax incentives for a certain categories of entrepreneurs who obtain the status of R\&D unit, or conduct their business activity on the territory of SEZ but they do not fit well to their needs. Taking the above weaknesses into account, an effective system involving a mix of $R \& D$ tax incentives aimed at increasing $R \& D$ investment and intersectoral collaboration is especially desired. The diversified instruments should be targeted to support internal R\&D activities and mutual cooperation. Particularly, more generous tax incentives for small and young innovative enterprises are worth regarding. The expected law changes with respect to income tax can contribute to the increase in business $R \& D$ expenditure and the growth of innovativeness in Polish economy.

\section{References}

[1] Innovation Union Scoreboard 2014, European Commission, Brussels, 2014.

[2] P. Mohnen, "R\&D Tax Incentives", Innovation for Growth-i4g Policy Brief $\mathrm{N}^{\circ} 25$, European Commission, Luxemburg, 2014, pp.1-7.

[3] M. Burnat-Mikosz, M. Turczyk, Inwestycje w $B+R-$ jak to robią najlepsi?, Delloitte, Warszawa, 2013.

[4] Global Research\&Development Incentives Group, PwC 2014, pp.7-29

[5] “A Study on R\&D Tax Incentives. Final Report", Working Paper No. 52, European Commission, Luxemburg, 2014, pp. 30-110.

[6] Summary Description of R\&D Tax Incentive Schemes for OECD Countries and Selected Economies, 2013, OECD 2014, http://www.oecd.org/sti/rd-tax-stats.htm

[7] I. Busom, B. Corchuelo, E. Martinez-Ros, "Tax incentives...or subsidies for business R\&D”, Small Business Economics, vol. 43, 2014, p. 571.

[8] A. Bozio, D. Irac, L. Py, Impact of Research Tax Credit on R\&D and Innovation: Evidence from the 2008 French Reform, DOCUMENT DE TRAVAIL N ${ }^{\circ} 532$, Banque De France, Paris, December 2014, pp. 5-10.

[9] J. Szlęzak-Matusewicz, "Models of Tax Incentives For R\&D Activities of Enterprises in European Union Countries" , Copernican Journal of Finance\&Accounting, vol. 3, issue 1, 2014, pp.149-158.

[10] J. J. Cordes, "Tax Incentives and R\&D Spending: A Review of the Evidence", Research Policy, vol. 18, 1989, pp. 119-133.

[11] N. Bloom, R. Griffin, J. van Reenen, "Do R\&D tax credits work? Evidence froma pane of countries 1979-1997”, Journal of Public Economics, vol. 85, issue 1, 2002, pp. 1-31.

[12] T. Hægland, J.Møen, "The relationship between the Norvegian R\&D tax credit scheme and other innovation policy instruments", Statistics Norway Reports, No. 45, 2007, pp. 1-31.

[13] E. Duguet, The Effect of the R\&D Tax Credit on the Private Funding of R\&D: An Econometric Evaluation on French Firm Level Data, Duguet, Emmanuel, 2010, pp.1-34, http://dx.doi.org/10.2139/ssrn.1592988 .

[14] J. Warda, "Tax Treatment of Business Investments in Intellectual Assets: An International Comparison”, STI Working Paper No. 4, OECD, Paris, 2006, pp. 1-51 .

[15] L. A. Stewart, J. Warda, R. D. Atkinson, We're \#27: The United States lags far behind in R\&D tax incentives generosity, ITIF 2012, pp.1-21.

[16] Business enterprise sector R\&D expenditure, http://ec.europa.eu/eurostat/eurostat/tgm/table.do?tab=table\&init=1\&plu gin $=1 \&$ language $=e n \& p \operatorname{code}=t s c 00001$, [accessed :15 FEB 2015].

[17] IBEC submittion to the Department of Finance, Review of the R\&D tax credit scheme, IBEC 2013, pp. 1-39.

[18] Information regarding corporate income tax settlement in 2013, Ministry of Finance, Warsaw 2014, p. 11.

About Author (s): Anna Wildowicz-Giegiel - is an assistan professor in Treasury Department at the University of Bialystok. Her research interests are related with the problem of intellectual capital creation and its impact on competitiveness under the conditions of new economy.

Professor Ryta Dziemianowicz - is the head of the Treasury Department at The Faculty of Economics and Management, Univesity of Bialystok. Her research interests include the analysis of public finance system in the context of its efficiency, and the problem of tax ependitures under a given tax regime. 